\title{
Evidence based study of Hypoglycemic Potential of Bitter Melon Peptide
}

\author{
Yu-Cheng Lin ${ }^{1}$ and Pang-Kuei Hsu ${ }^{2 *}$ \\ ${ }^{1}$ Institute of Food Science and Technology, National Taiwan University, Taiwan \\ ${ }^{2}$ Greenyn Biotechnology Co. Ltd., Taichung, Taiwan
}

*Corresponding author: Pang-Kuei Hsu, Greenyn Biotechnology Co., Ltd., Daya, Taichung City 42881, Taiwan.

To Cite This Article: Yu-Cheng Lin, Pang-Kuei Hsu. Evidence based study of Hypoglycemic Potential of Bitter Melon Peptide. 2020 - 9(1). AJBSR.MS.ID.001352. DOI: 10.34297/AJBSR.2020.09.001352.

Received: 㠿 May 08, 2020; Published: 畊 June 01, 2020

\begin{abstract}
Momordica charantia ( $M$. charantia), commonly referred to as bitter melon was received much attention for its anti-diabetic properties in recent years. The aim of this review was to discuss the bioactive peptides in bitter melon through their in vitro, in vivo and clinical studies for diabetes. Research showed that bitter melon peptides acted as the $\alpha$-amylase or $\alpha$-glycosidase inhibitor delayed the absorption of glucose from carbohydrates. Another noteworthy mechanism was the glucose intake regulation by insulin-like activities to enhanced insulin receptor kinase activity which activated IR signaling transduction pathway, resulted the translocation of glucose transporter 4, and uptake of glucose to cells. The remarkable effect of bitter melon peptide (mcIRBP-19) in patients with diabetes was also reported in the clinical study. This study summarized the scientific evidence of bitter melon peptides in regulating blood sugar levels through bioactive mechanisms. The bioactive peptides from bitter melon might open up new opportunities for the management of diabetes.
\end{abstract}

\section{Diabetes Mellitus}

Diabetes mellitus (DM) was considered as one of the five leading causes of death in the world. It was a syndrome of disordered metabolism, usually due to a combination of hereditary and environmental causes, and attributed to defective insulin secretion, resistance to insulin action, or a combination of both. On the basis of the pathogenic process that lead to hyperglycemia, diabetes was classified into type 1 diabetes (insulin-dependent) and type 2 diabetes (non-insulin-dependent) [1,2]. Ordinarily, the people below 18 age suffered from the type 1 diabetes, whereas type 2 diabetes mainly occurred in adult and old age group. According to the World Health Organization, approximately $10 \%$ of all diabetes cases were type 1 , and the remaining $90 \%$ cases of diabetes worldwide were of type 2, the number of people with DM worldwide had soared from 128 million in 1980 to 422 million in 2014. DM was one of the major threats to human life in many countries. Health-care professionals usually recommend controlling patients' blood sugar levels through a combination of drugs, diet controls, and regular physical exercise [3-5]. Still, no drug was available which had the ability to completely cure type 2 diabetes. Generally, to treat type 2 diabetes, oral hypoglycemic agents were used [6].

\section{Peptides from Bitter Melon}

Bitter melon was a common vegetable that displays antidiabetic potential. Many reports indicated that peptide extracts from MC showed various anti-hyperglycemic activities (Table 1). The anti-diabetic mechanisms from bitter melon peptide such as $\alpha$-glucosidase inhibitors, $\alpha$-amylase inhibitors and insulin mimetics activities were shown in Figure 1.

\begin{tabular}{|c|c|c|c|c|c|}
\hline \multicolumn{2}{|l|}{ Table 1: Reported peptides from bitter melon for anti-hyperglycemic activity. } & Dosage & Results \\
\hline Ser NO & Activities & Studies & Ref. \\
\hline 1 & $\begin{array}{c}\alpha \text {-amylase and } \alpha \text {-glucosidase } \\
\text { inhibitor }\end{array}$ & $\begin{array}{c}\text { Streptozotocin-induced. Wistar } \\
\text { rats, male, 3 months old. }\end{array}$ & I.G. 10 mg/kg body weight & AUC decreased 20.6\% & {$[7]$} \\
\hline 2 & Insulin mimetic & $\begin{array}{c}\text { alloxan-induced. Kunming mice, } \\
\text { male. }\end{array}$ & $\begin{array}{c}\text { I.V. 2.5 mg/Kg body } \\
\text { weight }\end{array}$ & $\begin{array}{c}\text { on glucose tolerance test FBG } \\
\text { decreased 78.0\% in } 4 \mathrm{hr}\end{array}$ & {$[8]$} \\
\hline
\end{tabular}




\begin{tabular}{|c|c|c|c|c|c|}
\hline 3 & $\begin{array}{l}\text { Insulin mimetic or Insulin } \\
\text { Secretion Stimulated }\end{array}$ & $\begin{array}{l}\text { alloxan-induced. Kunming mice, } \\
\text { male. }\end{array}$ & I.G. $40 \mathrm{mg} / \mathrm{kg}$ body weight & $\begin{array}{l}\text { FBG decrease } 61.1 \% \text { on } \\
\text { glucose tolerance test: }\end{array}$ & [9] \\
\hline 4 & $\alpha$-glucosidase inhibition & $\begin{array}{l}\text { Streptozotocin-induced. Wistar } \\
\text { rats, male, } 3 \text { months old. }\end{array}$ & I.P. $25 \mathrm{mg} / \mathrm{kg}$ body weight & $\begin{array}{c}\text { on glucose tolerance test: } \\
-67.2 \% 2 \mathrm{hr}\end{array}$ & [10] \\
\hline 5 & Insulin mimetic & $\begin{array}{l}\text { Streptozotocin-induced. BALB/c } \\
\text { mice, male, } 6 \text { weeks old. }\end{array}$ & $\begin{array}{l}\text { I.P. } 2.5 \mathrm{nmol} / \mathrm{kg} \text { body } \\
\text { weight }\end{array}$ & AUC decreased $20.9 \%$ & {$[2]$} \\
\hline 6 & Insulin mimetic & $\begin{array}{l}\text { Streptozotocin-induced. } \mathrm{db} / \mathrm{db} \\
\text { mice, male, } 8 \text { weeks old. }\end{array}$ & $\begin{array}{l}\text { I.P. } 0.5 \mathrm{nmol} / \mathrm{kg} \text { body } \\
\text { weight }\end{array}$ & AUC decreased $20 \%$ & [11] \\
\hline 7 & Insulin mimetic & Clinical Trials & P.0. $600 \mathrm{mg} /$ day & $\begin{array}{c}\text { FG decreased } 13.7 \% \text { HbA1c } \\
\text { decreased } 5.13 \%\end{array}$ & [12] \\
\hline
\end{tabular}

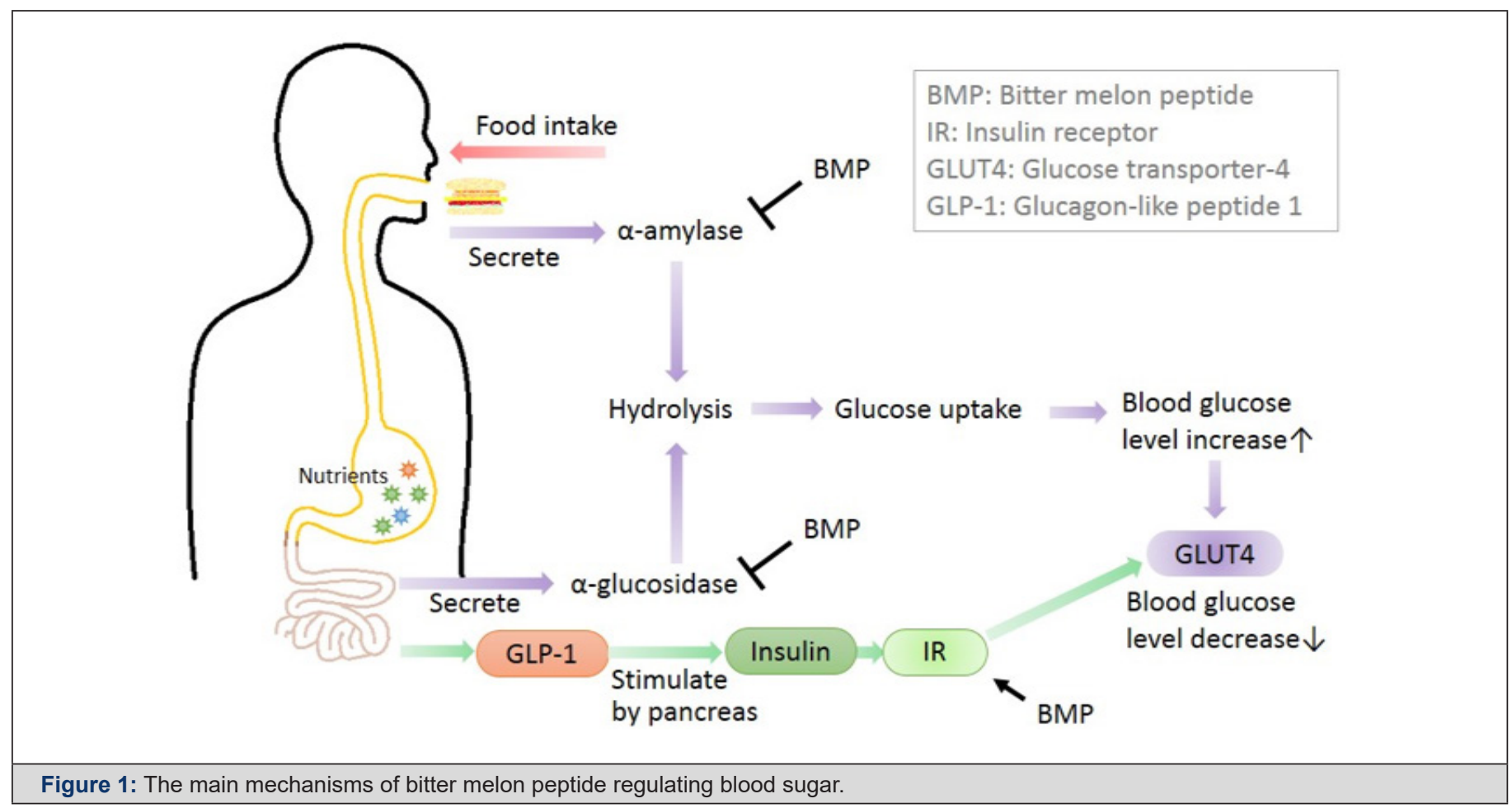

\section{$\alpha$-Amylase and $\alpha$-Glucosidase Inhibitors}

Some risk factors involved in DM were mainly due to postprandial hyperglycemia. Dietary carbohydrates were broken down into simple mono saccharides by a group of digestive enzymes called $\alpha$-amylase, $\alpha$-glucosidases and elevated postprandial hyperglycemia was due to action of these enzymes. Postprandial hyperglycemia in diabetes could be managed by inhibiting $\alpha$-glucosidase. Inhibitors of this enzyme decreased the glucose toxicity (improved insulin sensitivity) and stress on beta cells (decreases post-meal hyperglycemia), increased glucagon like peptide-1 (GLP-1) production hence stimulating insulin secretion [13]. Marella et al. [10] reported that MCP showed inhibitory activity on $\boldsymbol{\alpha}$-glucosidase and aldose reductase enzymes in in vitro test and a significant decrease in fasting blood glucose levels (267.1 $\pm 11.2 \mathrm{mg} / \mathrm{dL}$ to $87.5 \pm 12.0 \mathrm{mg} / \mathrm{dL}$ ) with MCP treated diabetic rats was discussed. Poovitha and Parani [7] also reported that the maximum of 68.8 and $69.2 \%$ inhibition of $\alpha$-glucosidase activity was observed at $2.5 \mathrm{mg} / \mathrm{mL}$ concentration for the MCP from two different bitter melon spices, respectively. And the maximum $66.5 \%$ and $67 \%$ inhibition of $\alpha$-amylase activity was observed at the same dosage. The Line weaver-Burk plot showed that the MCP inhibited the $\alpha$-amylase and $\alpha$-glucosidase enzymes by competitive binding. In vivo studies revealed peak blood glucose (PBG) and area under the curve (AUC) were significantly reduced in the diabetic rats with orally administered with the protein extracts after starch or sucrose loading.

\section{Insulin mimetic}

Bitter melon contained a high dosage of 'plant insulin' [14] and effectively lowered blood sugar by reducing the speed of nephropathy development in streptozotocin (STZ)-induced diabetic rats [15], improving intestinal disorders caused by diabetes [16], enhancing the function of the intestine, and delaying development of cataracts [17]. Researches further indicated that bitter melon peptide had a hypoglycemic effect upon insulin-like biological activity and could regulate blood sugar to normal levels. 
As shown in Figure 2, insulin binding to insulin receptor (IR) stimulated the auto-phosphorylation of IR, leading to the activation of phosphoinositide-3-kinase (PI3K) and Akt, the translocation of glucose transporter 4 (GLUT4), and the subsequent glucose uptake of adipocytes and skeletal muscle [18]. Lo et al. [11] identified a hypoglycemic polypeptide, Momordica charantia insulin receptor (IR)-binding protein (mcIRBP) which was identified a novel 68-residue (mcIRBP-68). After digestion of mcIRBP-68 by simulated gastric and intestinal fluids, the peptide fragments were analyzed by LC-ESI-MS/MS. Five digestive residues of mcIRBP-68 were analyzed and the 19 amino acid residue consensus peptide(mcIRBP-19) had shown the highest IR binding activity by expressing as relative radioactivity from $\left[{ }^{125} \mathrm{I}\right]$-insulin in IL-9 cell culture test. Study reported mcIRBP-19 was a putative IR-binding and blood glucose-lowering bioactive peptide. The mcIRBP-19 activated the kinase activity of IR, stimulated the IR-downstream signaling transduction pathway, enhanced the expression of GLUT4, and increased the glucose clearance in diabetic mice.

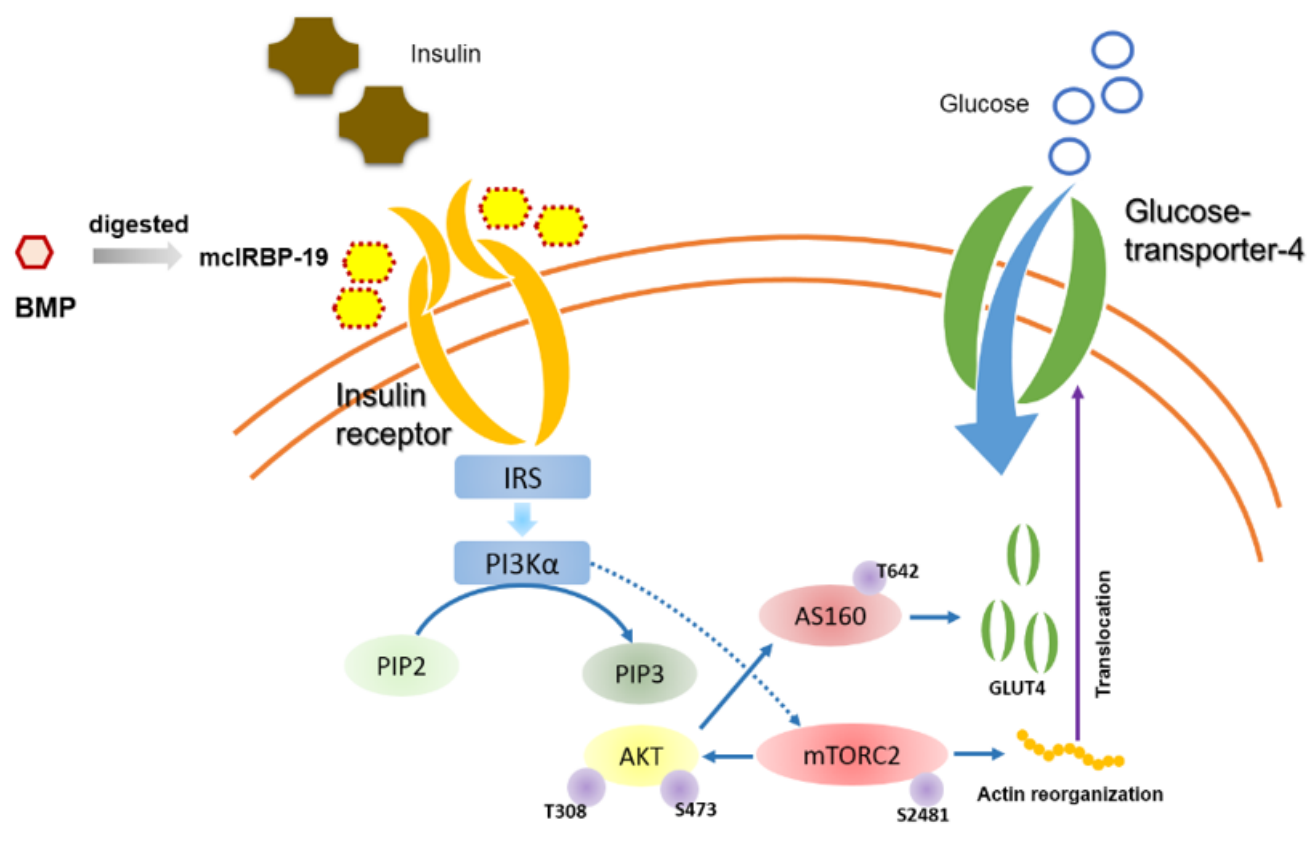

Figure 2: Signal transduction effects of mcIRBP-19 in regulating glucose metabolism.

Hsu et al. [12] also indicated that bitter melon extract (contains mcIRBP-19) clinically regulated blood sugar levels in diabetes patients. After 12 weeks trials with a total of 142 subjects included in the study, results showed bitter melon peptide significant regulated the FG and HbA1c levels of patients. The findings provided the evidence that helps to verify the effectiveness of the bitter melon peptide in regulating diabetic patients' blood sugar levels, and gave a hint that bitter melon peptide has the high potential of oral plant insulin for the treatment of type $1 \& 2$ diabetes.

\section{Conclusion}

Epidemiological data revealed that type 2 diabetes required promising therapy to reduce the severe adverse effects of synthetic drugs. The bitter melon peptides with multiple mechanism could help to maintain the levels of blood sugar, such as inhibiting the enzymes like $\alpha$-glucosidase and $\alpha$-amylase, and insulin-mimetic activity from bioactive peptides (mcIRBP-68 and mcIRBP-19). Recent studies also suggested that a regular intake of bitter melon peptides may benefit other human organ functions. Although the bitter melon peptides should not be used to replace the DM patient's medication, bitter melon peptides had the potential to the future applications of the anti-diabetic material of health food or drug development. Further chemical and pharmacological studies should be conducted to confirm its effectiveness.

\section{References}

1. Joseph B, Jini D (2013) Antidiabetic effects of Momordica charantia (bitter melon) and its medicinal potency. Asian Pacific J Trop Dis 3(2): 93-102.

2. Lo HY, Ho TY, Li CC, Chen JC, Liu JJ, et al. (2014) A novel insulin receptorbinding protein from Momordica charantia enhances glucose uptake and glucose clearance in vitro and in vivo through triggering insulin receptor signaling pathway. J Agric Food Chem 62: 8952-8961.

3. Baynes H (2015) Classifcation, pathophysiology, diagnosis and management of diabetes mellitus. J Diabetes 6: 1-9.

4. Brownlee M (2005) The pathobiology of diabetic complications: A unifying mechanism. Diabetes 54: 1615-1625.

5. Chen JW, LauritzenT, Bojesen A, Christiansen JS (2006) Multiple mealtime administration of biphasic insulin as part 30 versus traditional basal-bolus human insulin treatment in patients with type 1 diabetes. Diabetes Obes 8: 682-689.

6. Shital PP, Ashutosh G, Kiran K, Abhijeet SK (2020) PlantDerived Bioactive Peptides: A Treatment to Cure Diabetes. Int J Pept Res Ther 26: 955-968. 
7. Poovitha S, Parani M (2016) In vitro and in vivo $\alpha$-amylase and $\boldsymbol{\alpha}$-glucosidase inhibiting activities of the protein extracts from two varieties of bitter gourd (Momordica charantia L) BMC Complement Altern Med 16(1): 185.

8. Wang BL, Zhang WJ, Zhao J, Wang FJ, Fan LQ, et al. (2011) Gene cloning and expression of a novel hypoglycaemic peptide from Momordica charantia. J Sci Food Agric 91(13): 2443-2448

9. Yuan XQ Gu XH, Tang JF, Wasswa J (2008) Hypoglycemic effect of semipurified peptides from Momordica charantia L. var. Abbreviata Ser. in alloxan-induced diabetic mice. J Food biochem 32(1): 107-121.

10. Marella S, Maddirela DR, Kumar EG, Tilak TK, Badri KR, et al. (2016) Mcy protein, a potential antidiabetic agent: evaluation of carbohydrate metabolic enzymes and antioxidant status. Int J Biol Macromol 6: 481488.

11. Lo HY, Li CC, Ho TY, Hsiang CY (2016) Identification of the bioactive and consensus peptide motif from Momordica charantia insulin receptorbinding protein. Food Chem 204: 298-305.
12. Hsu PK., Pan FFC, Hsieh CS (2020) mcIRBP-19 of Bitter Melon Peptide Effectively Regulates Diabetes Mellitus (DM) Patients' Blood Sugar Levels. Nutrients 28: 12(5).

13. Scheen AJ (2003) Is there a role for $\alpha$-glucosidase inhibitors in the prevention of type 2 diabetes mellitus? Drugs 63(10): 933-951.

14. Khanna P, Jain SC, Panagariya A, Dixit VP (1981) Hypoglycemic activity of polypeptide-p from a plant source. J Nat Prod 44: 648-655.

15. Grover JK, Vats V, Rathi SS, Dawar R (2001) Traditional Indian antidiabetic attenuate progression of renal damage in streptozotocin induced diabetic mice. J Ethnopharmacol 76(3): 233-238.

16. Grover JK, Yadav S, Vats V (2002) Medicinal plants of India with antidiabetic potential. J Ethnopharmacol 81(1): 81-100.

17. Rathi SS, Grover JK, Vats Vikrant, Biswas NR (2002) Prevention of experimental diabetic cataract by Indian Ayurvedic plant extracts. Phytother Res 16(8): 774-777.

18. Saltiel AR, Kahn CR (2001) Insulin signaling and the regulation of glucose and lipid metabolism. Nature 414: 799-806. 